\title{
Notes on Cynipid Galls, Ground Beetles and Ground-Dwelling Spiders Collected at Fort Severn, Ontario
}

\author{
JOSEPH D. SHORTHOUSE, ${ }^{1}$ HENRI GOULET ${ }^{2}$ and DAVID P. SHORTHOUSE ${ }^{3}$
}

(Received 22 November 2001; accepted in revised form 19 August 2002)

\begin{abstract}
A brief collecting trip to Fort Severn, Ontario $\left(55^{\circ} 59^{\prime} \mathrm{N}, 87^{\circ} 38^{\prime} \mathrm{W}\right)$, in May 2001 revealed galls of three species of cynipid wasps (Hymenoptera: Cynipidae) on the wild rose Rosa acicularis. Roses and cynipid galls occur along the banks of the Severn River above the tree line because of clay deposits, heat, and rafts of vegetation carried north by the river. Ground beetles and spiders were collected with pitfall traps. Our identification of 15 species of ground beetles (Coleoptera: Carabidae), two of them new records for Ontario, and 11 species of ground spiders (Araneae: Lycosidae), all new records for northwestern Ontario, indicates that the invertebrate fauna in the area has been poorly studied. Roads and trails away from Fort Severn, regularly scheduled airline service, and convenient accommodations make the area ideal for biological studies.
\end{abstract}

Key words: cynipid galls, wild roses, ground beetles, ground-dwelling spiders, Fort Severn

RÉSUMÉ. Une brève sortie de prélèvement à Fort Severn, en Ontario ( $55^{\circ} 59^{\prime}$ de lat. N., $87^{\circ} 38^{\prime}$ de long. O.), effectuée en mai 2001 a révélé l'existence de galles de trois espèces de cynips du rosier (hyménoptères: cynipidés) sur le rosier aciculaire Rosa acicularis. On trouve ce dernier et les galles du rosier le long des rives de la Severn au-dessus de la limite forestière en raison des dépôts d'argile, de la chaleur et de la végétation flottante que transporte la rivière en direction du Nord. On a prélevé des carabes et des araignées terricoles à l'aide de pièges à fosse. Notre identification de 15 espèces de carabes (coléoptères: carabidés), dont deux représentaient deux nouvelles espèces pour l'Ontario, et de 11 espèces d'araignées terricoles (aranéides: lycosidés), dont toutes étaient nouvelles pour le nord-ouest de l'Ontario, révèle que la faune invertébrée de la région n'a pas encore fait l'objet d'une étude approfondie. Les routes et les pistes menant à l'extérieur de Fort Severn, le service régulier de transport aérien et l'hébergement à proximité font de la région un emplacement idéal pour des études biologiques.

Mots clés: galles de cynips, rosiers aciculaires, carabes, araignées terricoles, Fort Severn

Traduit pour la revue Arctic par Nésida Loyer.

\section{INTRODUCTION}

While undertaking a study in May 2001 of the insect communities associated with galls induced by cynipid wasps (Hymenoptera: Cynipidae) on wild roses in northwestern Ontario, the first author spent three days during 18-21 May searching for roses near the Hudson Bay community of Fort Severn. Thirteen standard, plastic pitfall traps, with soapy solution in the bottom cup, were maintained throughout the stay to sample invertebrates. Stunted Rosa acicularis Lindl. with galls were found on the banks of the Severn River near the settlement, but the unexpected diversity of ground beetles (Coleoptera: Carabidae) and ground-dwelling spiders (Araneae: Lycosidae) relatively early in the season, and with so few traps, prompted this report. The ground beetles were sent to the second author and the spiders to the third author for identification and comment. Our purpose is to record information obtained on the rose galls, ground beetles, and ground-dwelling spiders at Fort Severn and draw attention to the potential of the area for biological studies near the tree line in Ontario.

\section{TERRAIN AND ECOSYSTEMS NEAR FORT SEVERN}

Fort Severn, Ontario's most northerly community ( $55^{\circ} 59^{\prime}$ $\mathrm{N}, 87^{\circ} 38^{\prime} \mathrm{W}$ ), is located in the northwest corner of the province near the mouth of the Severn River, $10 \mathrm{~km}$ from Hudson Bay (Fig. 1). The community of about 500 residents, most of whom are of the Nishnawbe Aski Nation, is on the west side of the river. There are no all-weather roads into the community; transportation into the region is possible by air, cargo boats, and a winter road from Gillam, Manitoba. The Severn River extends from Deer Lake (52 $37^{\prime}$ $\left.\mathrm{N}, 94^{\circ} 05^{\prime} \mathrm{W}\right)$ to Hudson Bay. The river near Fort Severn is broad (about $0.5 \mathrm{~km}$ across) and relatively shallow, with banks 4-8 $\mathrm{m}$ in height composed of clay and sand. Except when engorged by spring meltwater and ice, the Severn River empties serenely into Hudson Bay.

\footnotetext{
${ }^{1}$ Department of Biology, Laurentian University, Sudbury, Ontario P3E 2C6, Canada; jshortho@ nickel.laurentian.ca

${ }^{2}$ ECORC, Agriculture and Agri-Food Canada, K.W. Neatby Building, Ottawa, Ontario K1A 0C6, Canada

${ }^{3}$ Department of Biological Sciences, University of Alberta, Edmonton, Alberta T6G 2E9, Canada

(C) The Arctic Institute of North America
} 


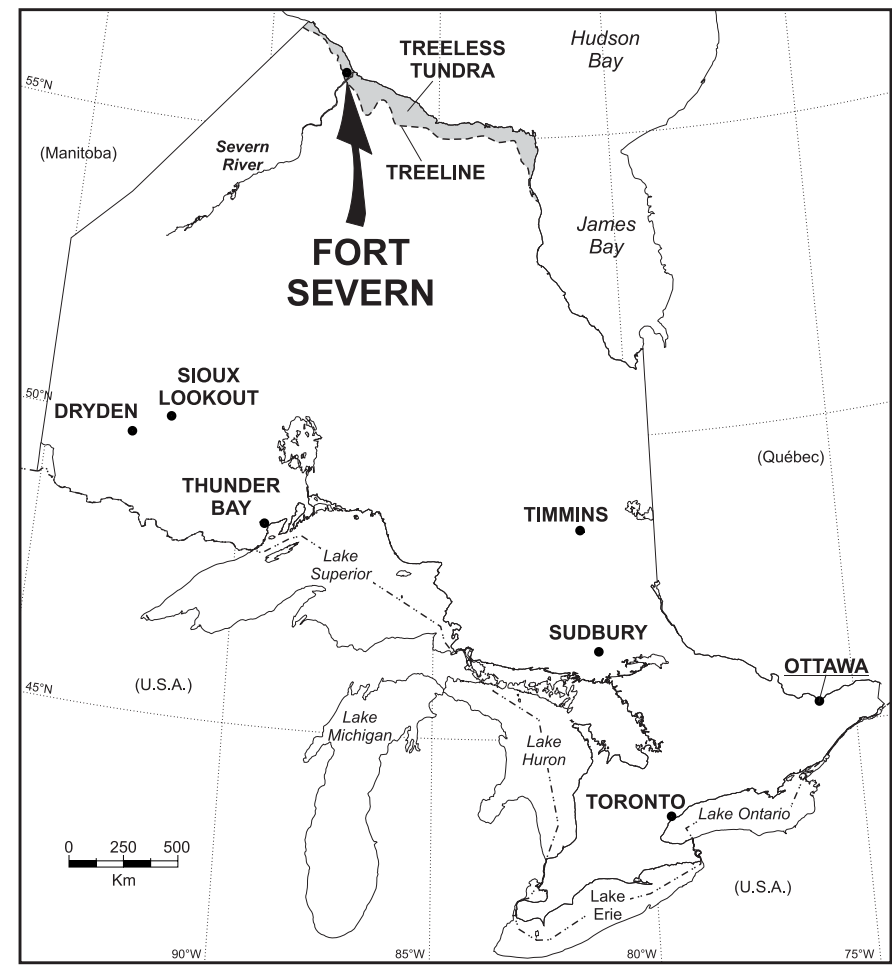

FIG. 1. Map showing location of Fort Severn, Ontario.

Fort Severn is in the Hudson Bay Lowlands, the third largest wetland in the world (Keddy, 2000). The community lies north of the northern boundary of the boreal zone, in a mostly treeless zone that Zoltai et al. (1988:61) called the "humid high Subarctic wetland region." This zone is about $20-30 \mathrm{~km}$ wide and extends along the coast of Hudson Bay from the border with Manitoba to Cape Henrietta Maria at the start of James Bay (Fig. 1). Much of this zone is underlain by permafrost and is the most southern Subarctic barrens in the world (Prevett, 1989). The Hudson Bay physiographic region is characterized by a flat topography that slopes gently to the sea (Rowe, 1972; Zoltai et al., 1988).

Fort Severn and its environs are characterized by cold winters and short, warm summers; the area has the coldest climate in Ontario. The coast of Hudson Bay is a harsh environment for vegetation because of advected cold winds blowing towards the land (Lescop-Sinclair and Payette, 1995). However, early snow cover in depressions and along river valleys protects vegetation from cold temperatures and abrasion by wind-driven snow (Scott et al., 1993).

Although much of the terrain beyond the river near Fort Severn is treeless, the alluvial banks in some areas provide suitable conditions for thick stands of various species of willow, alder, stunted black spruce (Picea mariana (P. Mill.)), and white spruce (Picea glauca (Moench)Voss) (Fig. 2A), while across the river from Fort Severn there are thick stands of balsam poplar (Populus balsamifera L.). Most of the terrain beyond the river is wetlands, but black and white spruce and tamarack (Larix lariciana (Du Roi)) are found in some areas near Fort Severn within 1-2 km of the river (Fig. 2B). In such sites, tamarack that is $3 \mathrm{~m}$ high and $6.5 \mathrm{~cm}$ in diameter may be 450 years old (Prevett, 1989). The 13 pitfall traps were installed along the sides of the riverbank (Fig. 2A) and in dry, sandy areas at the edge of conifer stands (Fig. 2B).

The banks of the river slowly decrease in height as the river approaches Hudson Bay, and conditions are too severe for trees to grow (Fig. 2C). An interesting feature near Fort Severn, and likely well to the south, is clumps of vegetation near the water's edge that have broken off from the banks above (Fig. 2D). It is suspected that many of these clumps, when broken from the banks during spring breakup, become 'rafts' and are transported northward, where some become lodged along the shore.

Fort Severn is ideal for studying northern biota because of the many roads and trails extending away from the community. One road several kilometres long extends westward towards the airport, and another extends northward along the riverbank (Fig. 2E). The north road is of value because it follows a gradient of declining vegetation complexity to the shores of Hudson Bay. The terrain from the shore of Hudson Bay to about $2 \mathrm{~km}$ inland is flat and dominated by grasses and stunted shrubs and spruce (Fig. 2F).

\section{CYNIPID GALLS ON ROSA ACICULARIS}

The only species of rose near Fort Severn is Rosa acicularis, common throughout Ontario (Soper and Heimburger, 1982). Another common species in most of Ontario, R. blanda Ait., is not found in the Hudson Bay Lowlands (Soper and Heimburger, 1982); however, it flourishes (commonly reaching heights of $1.5 \mathrm{~m}$ ) along the banks of the Moose River and on Moose Factory Island near Moosonee (J.D. Shorthouse, unpubl. observations). $R$. acicularis is found only on well-drained soils along the top of the river bank. About 50 stunted roses, each about $10-30 \mathrm{~cm}$ in height, were found along the road in Figure 2E.

Galls of three species of cynipid wasps of the genus Diplolepis, all induced in the summer of 2000, were found on these plants (Table 1). Three stem galls of D. triforma Shorthouse and Ritchie were found attached to shrubs in dense grass about $15 \mathrm{~cm}$ high. Galls of $D$. triforma are multi-chambered and fusiform and in central Ontario average $7 \mathrm{~mm}$ in width and $25 \mathrm{~mm}$ in length (Shorthouse and Ritchie, 1984). Those at Fort Severn averaged $6 \mathrm{~mm} \times$ $12 \mathrm{~mm}$. Galls in central Ontario are attacked by five species of parasitoids (Wiebes-Rijks and Shorthouse, 1992), but no adults of $D$. triforma or parasitoids exited the Fort Severn galls when they were brought to room temperature in the laboratory. Even so, the presence of galls confirms the establishment of this species at Fort Severn. If the inducers in these galls were not killed by parasitoids, they may have frozen to death. Diplolepis overwinter in a 

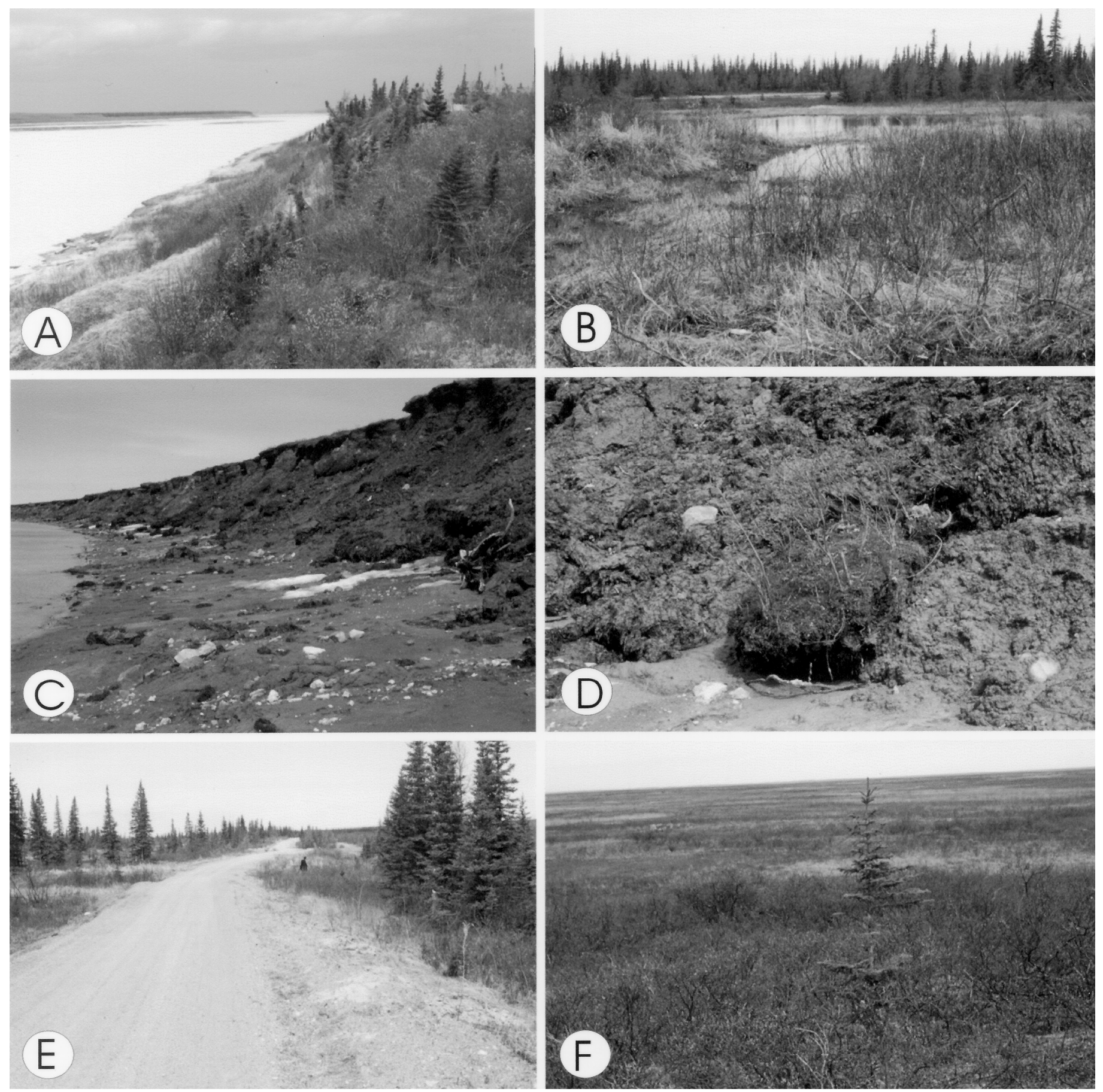

FIG. 2. A) West bank of the Severn River near the community of Fort Severn looking south. The banks are dominated by stunted white and black spruce, willows, and alders; B) Typical wetlands above the west bank of the Severn River, about $2 \mathrm{~km}$ north of Fort Severn. Dominant trees are black spruce and tamarack; C) Shallow banks of the Severn River about $4 \mathrm{~km}$ from Hudson Bay. Note the absence of trees. Permafrost was evident beneath about $0.5 \mathrm{~m}$ of peat moss; D) Raft of vegetation broken from the bank above by scouring effects of ice in the spring and caving in of the bank; E) Road north of Fort Severn parallel to the Severn River that extends to the shoreline of Hudson Bay; and F) Flatlands on the west side of the Severn River near Hudson Bay. Local residents report that black spruce and balsam poplar have become established in this area within the past 20 years.

prepupal stage; they are freezing-intolerant and develop cryoprotectants that lower their supercooling points (Williams et al., 2002). D. triforma in galls on the lower parts of plants and covered with leaf litter and snow likely avoid lethal winter temperatures.

Two leaves with all leaflets galled by $D$. rosaefolii (Cockerell) (Table 1) were found attached to roses about
$10 \mathrm{~cm}$ from the surface of the ground. D. rosaefolii induces small, lenticular galls about $2 \mathrm{~mm}$ thick and $4 \mathrm{~mm}$ in diameter that frequently coalesce and cover the entire surface of the leaflets (Shorthouse and Brooks, 1998). In central Ontario, eight species of parasitoids and a Periclistus inquiline are associated with this gall (Shorthouse, 1998). None of the Fort Severn galls issued inhabitants; however, 
TABLE 1. Distribution, general collection locales, and recorded habitats of the cynipid gall wasps of Fort Severn, Ontario.

\begin{tabular}{|c|c|c|c|}
\hline Species & Distribution & General Collection Locales & Recorded Habitat \\
\hline Diplolepis polita (Ashmead) ${ }^{1}$ & Nearctic & $\begin{array}{l}\text { Tree line south across Alaska, the Yukon, } \\
\text { Northwest Territories to northern Ontario and } \\
\text { Quebec; not found in Atlantic provinces; } \\
\text { throughout western provinces including islands } \\
\text { off the west coast; south to California. }\end{array}$ & $\begin{array}{l}\text { Wherever Rosa acicularis grows in meadows, } \\
\text { clearings, openings in woods, ridges, clay and } \\
\text { sand banks, river banks; } R \text {. woodsii Lindl. } \\
\text { growing in valleys in southern British } \\
\text { Columbia and } R \text {. arkansana Porter in moister } \\
\text { areas of southern Alberta. }\end{array}$ \\
\hline Diplolepis rosaefolii (Cockerell) $)^{2}$ & Nearctic & $\begin{array}{l}\text { Most widespread species in Canada; tree line } \\
\text { south across Alaska, the Yukon and likely } \\
\text { eastward to Quebec; all of Atlantic provinces, } \\
\text { only species of Diplolepis on island of } \\
\text { Newfoundland. Southern distribution into U.S. } \\
\text { not known. }\end{array}$ & $\begin{array}{l}\text { Wherever Rosa acicularis grows in meadows, } \\
\text { clearings, openings in woods, ridges, clay and } \\
\text { sand banks, river banks; on } R \text {. virginiana } \\
\text { Mill.in Martime provinces and on } R \text {. nitida } \\
\text { Willd. in Newfoundland. }\end{array}$ \\
\hline Diplolepis triforma Shorthouse and Ritchie ${ }^{3}$ & Nearctic & $\begin{array}{l}\text { Most northern records are in southern Yukon; } \\
\text { throughout British Columbia except for islands } \\
\text { off west coast; throughout Alberta, } \\
\text { Saskatchewan, Manitoba and Ontario; not } \\
\text { known east of Ontario/Quebec border; } \\
\text { southern distribution into U.S. not known. }\end{array}$ & $\begin{array}{l}\text { Rosa acicularis growing in meadows, } \\
\text { clearings, openings in woods, ridges, clay and } \\
\text { sand banks, river banks or } R \text {. woodsii in } \\
\text { valleys in southern British Columbia and along } \\
\text { river valleys in southern parts of prairie } \\
\text { provinces. }\end{array}$ \\
\hline
\end{tabular}

References: ${ }^{1}$ Shorthouse (1993); ${ }^{2}$ Shorthouse and Brooks (1998); ${ }^{3}$ Shorthouse and Ritchie (1984).

the presence of galls confirms that the species can survive here.

Five leaves with a total of 61 galls of $D$. polita (Ashmead) (Table 1) were also found; one cluster with 14 galls had not dehisced, and the other four were in the leaf litter at the base of plants. Galls of D. polita are spherical and spinulose, averaging from 3.5 to $12 \mathrm{~mm}$ in diameter, and are found in clusters on the adaxial surface of leaflets (Shorthouse, 1993). Nearly all galls dehisce by late August and overwinter in the leaf litter. Rarely do inhabitants of galls remaining on host plants survive the winter, but in this case adults of Periclistus inquilines and parasitoids emerged from both galls in the litter and galls on the plant. No $D$. polita issued from these galls, but 49 adult Periclistus, a common inhabitant of this gall (Shorthouse, 1993, 1998), did emerge, along with 3 Aprostocetus sp., 10 Pteromalus sp., and 1 Orthopelma sp., all of which are parasitoids that feed on the inducers and Periclistus. At least seven species of parasitoids are associated with this gall in central Ontario (Shorthouse, 1993). All adults are deposited in the collection of the first author at Laurentian University.

\section{GROUND BEETLES}

Ground beetles are important ground-dwelling predators found over much of the world (Erwin et al., 1979). They are well known taxonomically and ecologically, and they are among the best-known insects for studying biogeographical patterns ( Lindroth, 1961, 1963, 1966, 1968; Erwin et al., 1979; Bousquet, 1987). Most are capable of flight when disturbed, but they typically remain closely associated with the habitat(s) for which they are adapted. Ranges of most ground beetles are determined by climate and general features of habitat instead of specific types of food or particular assemblages of plants (Ball and Currie, 1997). Consequently, the present-day distribution patterns have been useful in formulating hypotheses about past distributions and histories of regional biota and climate (Kavanaugh, 1979). There are approximately 850 species known from Canada, 209 species in the Yukon (Ball and Currie, 1997), and 78 species from Arctic North America (Danks, 1981). Ground beetles have previously been collected in the Fort Severn, Hudson Bay coast, and Cape Henrietta regions (records in the Canadian National Collection of Insects in Ottawa [CNC]).

Fifteen species of ground beetles were collected at Fort Severn (Table 2). All are characteristic of northern assemblages; nine are Nearctic and six are Holarctic (Table 2). Six species (Calathus ingratus Dejean, Carabus chamissonis Fisher, Carabus meander Fisher, Pelophila rudis LeConte, Pterostichus adstrictus Eschscholtz, and Pterostichus patruelis Dejean) are already known from Fort Severn, or along the Hudson Bay coast; however, two species, Amara erratica (Duftschmi) and Bembidion morulum LeConte, are recorded from Ontario for the first time, and Platynus mannerheimi Dejean is recorded from Ontario for only the second time (CNC records). Dyschirius hiemalis Bousquet is known to be widespread in the boreal region, but is considered rare (Bousquet, 1987). Patrobus foveocollis Eschscholtz and Trichocellus cognatus Gyllenhal are rarely found in Ontario (CNC records). All beetles are deposited in the $\mathrm{CNC}$ in Ottawa.

\section{GROUND-DWELLING SPIDERS}

Ground-dwelling spiders are important and dominant predators in terrestrial ecosystems (Moulder and Reichle, 1972). Some collection data are available from areas such 
TABLE 2. Distribution, general collection locales, and recorded habitats of carabid ground beetles of Fort Severn, Ontario.

\begin{tabular}{|c|c|c|c|}
\hline Species & Distribution & General Collection Locales & Recorded Habitat \\
\hline Amara erratica Duftschmid & Holarctic $^{8}$ & Widespread, yet represents the first record for Ontario. ${ }^{8}$ & $\begin{array}{l}\text { Sandy or gravely, open grassy } \\
\text { and well drained areas. } .^{1,8}\end{array}$ \\
\hline Bembidion morulum LeConte & Nearctic ${ }^{6}$ & $\begin{array}{l}\text { Widespread. Not recorded from Ontario though recorded from } \\
\text { Labrador to Yukon. }{ }^{6}\end{array}$ & Moist, peaty soil. ${ }^{6}$ \\
\hline Calathus ingratus Dejean & Nearctic ${ }^{7}$ & $\begin{array}{l}\text { Widespread in Canada and recorded previously from Fort } \\
\text { Severn. }{ }^{7}\end{array}$ & $\begin{array}{l}\text { Found in drained places with } \\
\text { leaf litter. }{ }^{1,7}\end{array}$ \\
\hline Carabus chamissonis Fisher & Nearctic ${ }^{5}$ & Widespread in Canada near tree line. Known from Fort Severn. ${ }^{5}$ & $\begin{array}{l}\text { Tundra or drained boreal } \\
\text { woodland. } .^{1,5}\end{array}$ \\
\hline Carabus meander Fisher & Holarctic $^{5}$ & $\begin{array}{l}\text { Widespread in Canada up to tree line. Known from Ft. Severn } \\
\text { and Cape Henrietta Maria. Considered rare. }{ }^{5}\end{array}$ & Moist areas or marshes. ${ }^{5}$ \\
\hline Dyschirius hiemalis Bousquet & Nearctic ${ }^{5}$ & $\begin{array}{l}\text { Widespread in boreal region, but rarely collected. In Ontario, } \\
\text { found only in northern part of the province. }{ }^{5}\end{array}$ & Dry, peaty habitats. ${ }^{5}$ \\
\hline Elaphrus lapponicus lapponicus Gyllenhal & Holarctic 4,5 & $\begin{array}{l}\text { Widespread in Canada, but recorded previously only from } \\
\text { Macdiarmid near Lake Nipigon in Ontario. }\end{array}$ & $\begin{array}{l}\text { Open wet and cold mossy places } \\
\text { without sphagnum. }{ }^{4,5}\end{array}$ \\
\hline Patrobus foveocollis Eschscholtz & Nearctic ${ }^{5}$ & Widespread in boreal regions. Rarely found in Ontario. ${ }^{5}$ & $\begin{array}{l}\text { In the shade on moist to wet } \\
\text { organic soils. }{ }^{1,5}\end{array}$ \\
\hline Pelophila rudis LeConte & Nearctic ${ }^{5}$ & $\begin{array}{l}\text { Recorded in western Canada as far as northern Ontario and also } \\
\text { Labrador. Known from Fort Severn and Cape Henrietta Maria in } \\
\text { Ontario. }\end{array}$ & Wet marshes with tussocks. ${ }^{7}$ \\
\hline Platynus mannerheimi Dejean & Nearctic ${ }^{7}$ & $\begin{array}{l}\text { Widespread, yet represents the second record for Ontario. Found } \\
\text { in Churchill, Manitoba. }{ }^{7}\end{array}$ & $\begin{array}{l}\text { Forested sites with moist to wet } \\
\text { organic soils. }\end{array}$ \\
\hline Pterostichus adstrictus Eschscholtz & Holarctic $^{7}$ & Widespread including Fort Severn. & $\begin{array}{l}\text { Wide range of forested and open } \\
\text { habitats., }\end{array}$ \\
\hline Pterostichus brevicornis Kirby & Holarctic $^{7}$ & $\begin{array}{l}\text { Widespread in boreal and southern tundra regions. Widespread } \\
\text { along the Hudson Bay coast. }{ }^{7}\end{array}$ & $\begin{array}{l}\text { Drained sites such as grassy } \\
\text { tundra. } .^{1,7}\end{array}$ \\
\hline Pterostichus patruelis Dejean & Nearctic ${ }^{7}$ & $\begin{array}{l}\text { Widespread in boreal and southern tundra regions. }{ }^{7} \text { Widespread } \\
\text { along the Hudson Bay coast. Ft. Severn is likely the most } \\
\text { northern record for this species. }\end{array}$ & $\begin{array}{l}\text { Drained sites such as grassy } \\
\text { tundra. }{ }^{1,7}\end{array}$ \\
\hline Pterostichus punctatissimus Randall & Nearctic ${ }^{7}$ & $\begin{array}{l}\text { East of Rockies in boreal regions, which includes Ft. Severn and } \\
\text { Cape Henrietta Maria. }\end{array}$ & $\begin{array}{l}\text { Moist forest with large moss } \\
\text { carpets. }{ }^{1,7}\end{array}$ \\
\hline Trichocellus cognatus Gyllenhal & Holarctic ${ }^{8}$ & Widespread in boreal regions although rarely found in Ontario. ${ }^{8}$ & $\begin{array}{l}\text { A boreal species found in well- } \\
\text { drained semi-open forest to } \\
\text { grassy spots, but not previously } \\
\text { collected on tundra. }{ }^{8}\end{array}$ \\
\hline
\end{tabular}

References: ${ }^{1}$ Larochelle (1975); ${ }^{2}$ Bousquet and Larochelle (1987); ${ }^{3}$ Goulet (1974); ${ }^{4}$ Goulet (1983); ${ }^{5} \operatorname{Lindroth}(1961)$; ${ }^{6}$ Lindroth (1963); ${ }^{7}$ Lindroth (1966); ${ }^{8}$ Lindroth (1968). Nomenclature from Bousquet (1987).

as Devon Island and Lake Hazen on Ellesmere Island (Leech, 1966; Leech and Ryan, 1972), the Yukon (Dondale et al., 1997), northern Manitoba (Aitchison-Benell and Dondale, 1990), and northern Quebec (Koponen, 1992, 1994). Spiders have also been collected in other northern parts of the world such as Alaska (Chamberlin and Ivie, 1947), Siberia (Marusik et al., 1993), and northern Europe (Koponen, 1996).

Over the three days, 34 identifiable spiders belonging to 11 species were collected at Fort Severn (Table 3). All are new records for northern Ontario, as apparently spiders have never been previously collected in the southwestern Hudson Bay Lowlands. Most are known from northern parts of Canada, and all from the floors of northern boreal forests. Koponen (1992) intensively collected spiders on the low Arctic Belcher Islands near the eastern shore of Hudson Bay at approximately the same latitude as Fort Severn. He used 75 pitfall traps throughout each of two growing seasons, capturing 674 specimens belonging to 23 species, thus providing an opportunity to compare his more comprehensive species list to that of the present study. Only one species, Arctosa insignita (Thorell), was collected in both studies, illustrating that spiders in the Fort Severn area are drawn from different regional pools. The findings emphasize that spiders in the low Arctic are poorly known and that even minimal collecting efforts, 
TABLE 3. Distribution, general collection locales, and recorded habitats of ground-dwelling spiders of Fort Severn, Ontario.

\begin{tabular}{|c|c|c|c|c|}
\hline Family & Species & Distribution & General Collection Locales & Recorded Habitat \\
\hline Amaurobiidae & Cybaeopsis euoplus (Bishop \& Crosby) & Nearctic $^{1}$ & $\begin{array}{l}\text { Nova Scotia and Newfoundland } \\
\text { west to British Columbia, north } \\
\text { to the western part of the } \\
\text { Northwest Territories. }^{7}\end{array}$ & $\begin{array}{l}\text { Dead deciduous leaf litter. Boreal forests } \\
\text { and bogs. } .^{1,7}\end{array}$ \\
\hline Clubionidae & Clubiona furcata (Emerton) & Holarctic $^{1}$ & Alaska to Newfoundland. ${ }^{5}$ & $\begin{array}{l}\text { Boreoalpine. Deciduous woods, bogs, } \\
\text { tall-grass meadows. Leaf litter. }{ }^{1,5}\end{array}$ \\
\hline Gnaphosidae & Gnaphosa muscorum (L. Koch) & Holarctic $^{1}$ & $\begin{array}{l}\text { Alaska to Labrador and Nova } \\
\text { Scotia. }{ }^{8}\end{array}$ & $\begin{array}{l}\text { Boreal forest. Coniferous woods, } \\
\text { deciduous woods, bogs, beaches, ditches. } \\
\text { Leaf litter. Under stones, logs, and pieces } \\
\text { of fallen bark in open pine and spruce } \\
\text { forests. }{ }^{1,8}\end{array}$ \\
\hline \multirow[t]{3}{*}{ Linyphiidae } & Lepthyphantes alpinus (Emerton) & Holarctic ${ }^{1}$ & Alaska to Newfoundland. ${ }^{2}$ & $\begin{array}{l}\text { Boreoalpine. Mixed woods. Coniferous } \\
\text { and deciduous leaf litter, moss, lake- } \\
\text { shore litter. }^{1}\end{array}$ \\
\hline & Grammonota maritima (Emerton) & Nearctic ${ }^{3}$ & Saskatchewan to Newfoundland ${ }^{3}$ & Maritime and freshwater beaches. ${ }^{3}$ \\
\hline & Tapinocyba parva (Kulczynski) & Holarctic $^{2}$ & Northern North America. ${ }^{3}$ & Unknown. \\
\hline Lycosidae & Arctosa insignita (Thorell) & Nearctic ${ }^{1}$ & $\begin{array}{l}\text { Alaska to Baffin Island and } \\
\text { Labrador. }{ }^{6}\end{array}$ & Tundra. ${ }^{1}$ \\
\hline Lycosidae & Pardosa fuscula (Thorell) & Nearctic $^{1}$ & Alaska to Newfoundland. ${ }^{6}$ & $\begin{array}{l}\text { Moist habitats, mainly fresh and salt } \\
\text { marshes, bogs, swamps, beaches and } \\
\text { meadows, but occasionally in alpine } \\
\text { tundra or conifer forests, or in forage } \\
\text { crops. Also litter under stones and } \\
\text { grass. }{ }^{1,6}\end{array}$ \\
\hline Lycosidae & Pardosa groenlandica (Thorell) & Holarctic $^{1}$ & $\begin{array}{l}\text { Alaska to Newfoundland, south } \\
\text { to Alberta, the Great Lakes. }{ }^{6}\end{array}$ & $\begin{array}{l}\text { Cobblestone beaches (both tidal and } \\
\text { freshwater) and gravel bars in creeks and } \\
\text { rivers, pebbly beaches, roadsides, fields, } \\
\text { river banks. }{ }^{1,6}\end{array}$ \\
\hline Theridiidae & Robertus fuscus (Emerton) & Nearctic $^{1}$ & Alaska to Newfoundland. ${ }^{3}$ & Boreal forest. Mixed woods. ${ }^{1}$ \\
\hline Thomisidae & Xysticus britcheri Gertsch & Holarctic $^{1}$ & Alaska to Newfoundland. ${ }^{4}$ & $\begin{array}{l}\text { Boreal. Bogs, sloughs, fields. Leaf litter. } \\
\text { Wooded areas. }{ }^{1,4}\end{array}$ \\
\hline
\end{tabular}

References: ${ }^{1}$ Aitchison-Benell and Dondale (1990); ${ }^{2}$ Buckle et al. (2001); ${ }^{3}$ D.J. Buckle (pers. comm. 2002); ${ }^{4}$ Dondale and Redner (1978); ${ }^{5}$ Dondale and Redner (1982); ${ }^{6}$ Dondale and Redner (1990); ${ }^{7}$ Leech (1972); ${ }^{8}$ Platnick and Dondale (1992). Nomenclature from Platnick (1997).

such as that at Fort Severn, are greatly rewarded. Samples of all spiders are at Laurentian University and with D. Shorthouse at the University of Alberta.

\section{CONCLUSIONS}

The Hudson Bay Lowlands is one of the most poorly studied areas of Canada with respect to its invertebrate fauna. This is mainly because the vast bogs and fens make the area almost impossible to traverse in the summer months; about the only way to penetrate the area is by boat or canoe. One of the few overviews of insect fauna near Hudson Bay is that of Oliver (1968), who reported that most entomological work in the area up to that time had been undertaken by investigators with the Northern Biting Fly Program in the 1940s and the Northern Insect Survey in the 1950s. Although both groups emphasized the biting flies (Diptera make up about half the species), other insects were collected as well, and most are housed in the CNC in Ottawa. Oliver (1968) also suggested that the insect fauna now inhabiting the Hudson Bay Lowlands, a select group able to tolerate low temperatures and a short growing season, invaded from the south, whereas many of the western Canadian insects currently north of the tree line came from the Beringian refugium. Oliver (1968) postulated that fewer than 1000 species of insects live north of the tree line, but some 10000 occur within a short distance south of that boundary.

Most insects now present near Fort Severn likely dispersed to the area by flying. Flight is important for dispersal in insects, as it enables them to escape quickly from unfavourable environmental conditions, find suitable places for survival, and maintain breeding connections in 
populations. Some adult Diplolepis may have been blown north by spring winds, but most likely became established in the area by rafts of vegetation (Fig. 2D) with galled roses that broke from banks of the river to the south and were carried north. Although the presence of galls of three species of Diplolepis establishes their presence at Fort Severn, survival of viable populations may be perilous because of harsh conditions. Large populations of galls of $D$. triforma and $D$. polita, and smaller population of galls of $D$. rosaefolli, $D$. bicolor (Harris) and $D$. radicum (Osten Sacken), were found on $R$. acicularis and $R$. blanda on Moose Factory Island in southern James Bay in 1998 and 1999 (J.D. Shorthouse, unpubl. data), suggesting that galls and their host plants have been carried north by rivers from elsewhere and are firmly established on river banks in northern areas that are otherwise inhospitable to roses. Much more study is required to understand the occurrence of Diplolepis galls and their inhabitants and how their ecological and physiological relationships with such northern regions differ from those farther south.

Ground beetles and spiders likewise may be carried northward on rafts of vegetation. Most northern ground beetles are capable of flying (Ball and Currie, 1997), which would benefit their dispersal once in the area, and spiders regularly disperse by ballooning. Sampling ground beetles and spiders by pitfall trapping over an entire season, both along the river and in the flats above, would likely reveal a much richer assemblage and confirm that floral and faunal assemblages in the riparian habitat have much in common with those in the boreal forest to the south.

Three days of exploring and sampling near Fort Severn in early spring revealed an unexpectedly high diversity of arthropods. Collecting fresh Diplolepis galls in August and returning them to the laboratory for overwintering in less harsh conditions would undoubtedly result in adults of all inhabitants. Galls of D. polita and D. rosaefolii are likely far more common than the May collections revealed, as galls in the leaf litter are difficult to locate compared to fresh galls still on the host plant. Likewise, adults of many species of carabids and spiders would not even be present in mid-May. Even so, our recording some species for the first time in Ontario should encourage others to undertake studies in the area.

Although records in the $\mathrm{CNC}$ indicate that entomologists have collected along the south shore of Hudson Bay, and botanists have collected near Fort Severn and along the Severn and Fawn Rivers (Soper and Heimburger, 1982), the flora and fauna of the region remain poorly known. However, by presenting the data obtained in one brief sampling trip in mid-May, we hope to draw attention to the potential of Fort Severn and its environs as a site for ecological and physiological study. The habitats and ecological gradients near Fort Severn are ideal for monitoring floral and faunal displacements near the tree line, studies that would be timely because of concerns that northern regions are particularly vulnerable to global climatic warming (Hughes, 2000; Morrison et al., 2000; Gough and Wolfe, 2001).

\section{ACKNOWLEDGEMENTS}

The trip to study northern galls was funded by grants from NSERC, the National Geographic Society, and the Laurentian University Research Fund. Léo Larivière drew the map and Mary Taylor made the plate of photographs from colour slides. Both are at Laurentian University. Summer student Brian Evans accompanied the first author to Fort Severn to help search for galls. Don Buckle verified the spider identifications.

\section{REFERENCES}

AITCHISON-BENELL, C.W., and DONDALE, C.D. 1990. A checklist of Manitoba spiders (Araneae) with notes on geographic relationships. Le Naturaliste Canadien 117:215-237.

BALL, G.E., and CURRIE, D.C. 1997. Ground beetles (Coleoptera): Trachypachidae and Carabidae) of the Yukon: Geographical distribution, ecological aspects, and origin of the extant fauna. In: Danks, H.V., and Downes, J.A., eds. Insects of the Yukon. Ottawa: Biological Survey of Canada (Terrestrial Arthropods). 445-489.

BOUSQUET, Y. 1987. The carabid fauna of Canada and Alaska: Range extensions, additions and descriptions of two new species of Dyschirius (Coleoptera: Carabidae). Coleopterist Bulletin 41:111- 135 .

BOUSQUET, Y., and LAROCHELLE, A. 1987. Catalogue of the Geadephaga (Coleoptera: Trachypachydae, Rhysodidae, Carabidae including Cicindelini) of America north of Mexico. Memoirs of the Entomological Society of Canada 167. 397 p.

BUCKLE, D.J., CAROLL, D., CRAWFORD, R.L., and ROTH, V.D. 2001. Linyphiidae and Pimoidae of America north of Mexico: Checklist, synonymy, and literature, Part 2. In: Paquin, P., and Buckle, D.J., eds. Contributions à la connaissance des Araignées (Araneae) d'Amérique du Nord. Fabrières, Supplément 10. 89-191.

CHAMBERLIN, R.V., and IVIE, W. 1947. The spiders of Alaska. Bulletin of the University of Utah, Biology Series 37(10). 103 p.

DANKS, H.V. 1981. Arctic arthropods: A review of systematics and ecology with particular reference to the North American fauna. Ottawa: Entomological Society of Canada. 608 p.

DONDALE, C.D., and REDNER, J.H. 1978. The crab spiders of Canada and Alaska (Araneae: Philodromidae and Thomisidae). The insects and arachnids of Canada, Part 5. Ottawa: Agriculture Canada. 255 p.

- 1982. The sac spiders of Canada and Alaska (Araneae: Clubionidae and Anyphaenidae). The insects and arachnids of Canada, Part 9. Ottawa: Agriculture Canada. 194 p.

- 1990. The wolf spiders, nurseryweb spiders and lynx spiders of Canada and Alaska. (Araneae: Lycosidae, Pisauridae, and Oxyopidae). The insects and arachnids of Canada, Part 17. Ottawa: Agriculture Canada. 383 p.

DONDALE, C.D., REDNER, J.H., and MARUSIK, Y.M. 1997. Spiders (Araneae) of the Yukon. In: Danks, H.V., and Downes, J.A., eds. Insects of the Yukon. Ottawa: Biological Survey of Canada (Terrestrial Arthropods). 73-113. 
ERWIN, T.L., BALL, G.E., WHITEHEAD, D.R., and HALPERN, A.L., eds. 1979. Carabid beetles: Their evolution, natural history, and classification. Proceedings of the First International Symposium of Carabidology, Smithsonian Institution, 21-25 August 1976, Washington, D.C. The Hague: Junk. 635 p.

GOUGH, W.A., and WOLFE, E. 2001. Climate change scenarios for Hudson Bay, Canada, from general circulation models. Arctic 54(2):142-148.

GOULET, H. 1974. Biology and relationships of Pterostichus pennsylvanicus LeConte (Coleoptera, Carabidae). Quaestiones Entomologicae 10:3-33.

1983. The genera of Holarctic Elaphrini and species of Elaphrus Fabricius (Coleoptera: Carabidae): Classification, phylogeny and zoogeography. Quaestiones Entomologicae 19:219-482.

HUGHES, L. 2000. Biological consequences of global warming: Is the signal already here? Trends in Ecology and Evolution 15:56-61.

KAVANAUGH, D.H. 1979. Investigations on present climate refugia in North America through studies on the distribution of carabid beetles: Concepts, methodology and prospectus. In: Erwin, T.L., Ball, G.E., Whitehead, D.R., and Halpern, A.L., eds. Carabid beetles: Their evolution, natural history, and classification. Proceedings of the First International Symposium of Carabidology, Smithsonian Institution, 21-25 August 1976, Washington, D.C. The Hague: Junk. 369-381.

KEDDY,P.A. 2000. Wetland ecology: Principles and conservation. Cambridge: Cambridge University Press.

KOPONEN, S. 1992. Spider fauna (Araneae) of the low arctic Belcher Islands, Hudson Bay. Arctic 45(4):358-362.

- 1994. Ground-living spiders, opilionids, and pseudoscorpions of peatlands in Quebec. Memoires of the Entomological Society of Canada 169:41-60.

. 1996. Diversity and similarity of northern spider faunas. Acta Zoologica Fennica 201:3-5.

LAROCHELLE, A. 1975. Les Carabidae du Québec et du Labrador. Département de Biologie du Collège Bourget, Rigaud. Bulletin 1. $255 \mathrm{p}$.

LEECH, R.E. 1966. The spiders (Araneida) of Hazen Camp 81 ${ }^{\circ} 49^{\prime}$ N, 71 ${ }^{\circ} 18^{\prime} \mathrm{W}$. Quaestiones Entomologicae 2:153-212.

-1972. A revision of the nearctic Amaurobiidae (Arachnida: Araneida). Memoirs of the Entomological Society of Canada 84. $182 \mathrm{p}$.

LEECH, R.E., and RYAN, J.K. 1972. Notes on Canadian Arctic spiders (Araneida), mainly from Devon Island, N.W.T. Canadian Entomologist 104:1787-1791.

LESCOP-SINCLAIR, K., and PAYETTE, S. 1995. Recent advance of the arctic treeline along the eastern coast of Hudson Bay. Journal of Ecology 83:929-936.

LINDROTH, C.H. 1961. The ground-beetles (Carabidae, excl. Cicindelinae) of Canada and Alaska, Part 2. Opuscula Entomologica Supplementum 20:1-200.

. 1963. The ground-beetles (Carabidae, excl. Cicindelinae) of Canada and Alaska, Part 3. Opuscula Entomologica Supplementum 24:201-408.
. 1966. The ground-beetles (Carabidae, excl. Cicindelinae) of Canada and Alaska, Part 4. Opuscula Entomologica Supplementum 29:409-648.

- 1968. The ground-beetles (Carabidae, excl. Cicindelinae) of Canada and Alaska, Part 5. Opuscula Entomologica Supplementum 33:649-944.

MARUSIK, Y.M., ESKOV, K.Y., KOPONEN, S., and VINOKUROV, N.N. 1993. A check-list of the spiders (Aranei) of Yakutia, Siberia. Arthropoda Selecta 2:63-79.

MORISON, J., AAGAARD, K., and STEELE, M. 2000. Recent environmental changes in the Arctic: A review. Arctic 53(4):359371.

MOULDER, B.C., and REICHLE, D.E. 1972. Significance of spider predation in the energy dynamics of forest-floor arthropod communities. Ecological Monographs 42:473-984.

OLIVER, D.R. 1968. Insects. In: Beals, C.S., ed. Science, History and Hudson Bay. Ottawa: Department of Energy, Mines and Resources. 416-436.

PLATNICK, N.I. 1997. Advances in spider taxonomy 1992-1995 with redescriptions 1940-1980. P. Merrett, ed. New York: New York Entomological Society. 976 p.

PLATNICK, N.I., and DONDALE, C.D. 1992. The ground spiders of Canada and Alaska (Araneae: Gnaphosidae). The insects and arachnids of Canada, Part 19. Ottawa: Agriculture Canada. 297 p.

PREVETT, J.P. 1989. Hudson Bay Lowlands and Polar Bear Provincial Park. In: Theberge, J.B., ed. Legacy: The natural history of Ontario. Toronto: McClelland and Stewart. 250-256.

ROWE, J.S. 1972. Forest regions of Canada. Publication No. 1300. Ottawa: Canadian Forestry Service. 172 p.

SCOTT, P.A., HANSELL, R.I.C., and ERICKSON, W.R. 1993. Influences of wind and snow on northern tree-line environments at Churchill, Manitoba, Canada. Arctic 46(4):316-323.

SHORTHOUSE, J.D. 1993. Adaptations of gall wasps of the genus Diplolepis (Hymenoptera: Cynipidae) and the role of gall anatomy in cynipid systematics. Memoires of the Entomological Society of Canada 165:139-163.

— . 1998. Role of Periclistus (Hymenoptera: Cynipidae) inquilines in leaf galls of Diplolepis (Hymenoptera: Cynipidae) on wild roses in Canada. In: Csóka, G., Mattson, W.J., Stone, G.N., and Price, P.W., eds. The biology of gall-inducing arthropods. General Technical Report NC-199. St. Paul, Minnesota: U.S. Department of Agriculture, Forest Service, North Central Research Station. 61-81.

SHORTHOUSE, J.D., and BROOKS, S.E. 1998. Biology of the galler Diplolepis rosaefolii (Hymenoptera: Cynipidae), its associated component community, and host shift to the shrub rose Thérèse Bugnet. Canadian Entomologist 130:357-366.

SHORTHOUSE, J.D., and RITCHIE, A.J. 1984. Description and biology of a new species of Diplolepis Fourcroy (Hymenoptera: Cynipidae) inducing galls on the stems of Rosa acicularis. Canadian Entomologist 116:1623-1636.

SOPER, J.H., and HEIMBURGER, M.L. 1982. Shrubs of Ontario. Toronto: Royal Ontario Museum. 495 p. 
WIEBES-RIJKS, A.A., and SHORTHOUSE, J.D. 1992. Ecological relationships of insects inhabiting cynipid galls. In: Shorthouse, J.D., and Rohfritsch, O., ed. Biology of insect-induced galls. Oxford: Oxford University Press. 238-257.

WILLIAMS, J., SHORTHOUSE, J.D., and LEE, R.E. 2002. Extreme resistance to desiccation and microclimate-related differences in cold-hardiness of gall wasps (Hymenoptera: Cynipidae) overwintering on roses in southern Canada. The Journal of Experimental Biology 205:2115-2124.

ZOLTAI, S.C., TARNOCAI, C., MILLS, G.F., and VELDHUIS, H. 1988. Wetlands of Subarctic Canada. In: The National Wetlands Working Group, Canada Committee on Ecological Land Classification. Wetlands of Canada. Ottawa: Environment Canada and Polyscience Publications. 58-96. 